\title{
Psoralen Analogues: Synthesis, Inhibitory Activity of Growth of Human Tumor Cell Lines and Computational Studies
}

Ana M. A. G. Oliveira ${ }^{\mathrm{a}}$, M. Manuela M. Raposo ${ }^{\mathrm{a}}$, Ana M. F. Oliveira-Campos ${ }^{\mathrm{a}}$, Antonio E. H. Machado ${ }^{\mathrm{b}}$

Prapawadee Puapairoj ${ }^{c, d}$, Madalena Pedro ${ }^{c}$, Maria São José Nascimento ${ }^{\text {cee }}$ César Portela $^{\mathrm{c}}$, Carlos Afonso ${ }^{\mathrm{c}, \mathrm{f}}$, Madalena Pinto* ${ }^{\mathrm{c}, \mathrm{f}}$

${ }^{a}$ Centro de Química, Universidade do Minho, Campus de Gualtar, 4710 Braga, Portugal.

${ }^{\mathrm{b}}$ Universidade Federal de Uberlândia - Instituto de Química, Laboratório de Fotoquímica/GFQM, P.O. Box 593, Uberlândia, 38408-100, Minas Gerais, Brasil.

${ }^{c}$ Centro de Estudos de Química Orgânica, Fitoquímica e Farmacologia da Universidade do Porto (CEQOFFUP), Faculdade de Farmácia, 4050-047 Porto, Portugal

${ }^{\mathrm{d}}$ Department of Pharmacology, Faculty of Medicine, Khonkhaen University, Khonkhaen Thailand

${ }^{\text {e }}$ Laboratório de Microbiologia, Faculdade de Farmácia da Universidade do Porto

${ }^{\mathrm{f}}$ Laboratório de Química Orgânica, Faculdade de Farmácia da Universidade do Porto

* Corresponding author. CEQOFFUP, Faculdade de Farmácia, Rua Aníbal Cunha, 167, 4050-047 Porto, Portugal; Tel: +351-222057358: Fax: +351-222003977;

e-mail: madalena@ff.up.pt 


\begin{abstract}
Eight psoralens have been evaluated for their ability to inhibit the in vitro growth of three human tumor cell lines representing different tumor types, MCF-7 (breast cancer), NCI-H460 (non-small cell lung cancer) and SF-268 (CNS cancer). The synthesis of four new psoralens (benzofurocoumarins) is presented as well as the results of the ab initio calculations to find the parameters that relate the structure with the antitumor activity. This work provides supplementary information that could allow the development of new psoralen analogues with this type of biological activity.
\end{abstract}

\title{
Keywords
}

Furocoumarins; Benzopsoralens; Antitumor; Computational studies 


\section{Introduction}

Psoralens have been known for a long time as photosensitizers for PUVA (psoralen and UVA therapy) [1]. A number of researchers became interested on studying the synthesis and biological properties of psoralen derivatives, including benzopsoralens $[1,2]$. The introduction of a benzene ring fused to the furan, or the addition of bulky or electron withdrawing substituents into the pyrone ring were suggested as potential ways of inhibiting adduct formation with DNA [3]. The possibility of formation of diadducts is suggested as being responsible for unwanted side effects $[1,4]$ The introduction of an ester group into a benzopsoralen can provide derivatives, which are efficient photosensitisers of singlet oxygen [2]. The presence of one or more methyl groups in psoralen analogues of the angelicin type, increases their photobinding ability to DNA [4]. Psoralen derivatives are also active in vitro against human melanoma cell line [5]. Recently the synthesis of compounds 1-4, containing an ester group in the position 3 of the pyranone ring was described (Scheme 1) [5]. Photophysical properties of the compounds 1 and $\mathbf{2}$ have been investigated, and it was shown that they could photochemically sensitise singlet oxygen generation, with a quantum efficiency near to unity [6]. It was decided to replace the ester group by another type of electron withdrawing group (compound $\mathbf{8}$ ) and/or to add extra substituent in position 4 of the pyranone ring. The photophysical properties of all new compounds are being evaluated. The present work describes the preparation and characterisation of four new analogues 5-8 (Schemes 1-3) as well as the results regarding the in vitro inhibitory effect on growth of three human tumor cell lines: MCF-7 (breast cancer), NCI-H460 (non-small cell lung cancer) and SF-268 (CNS cancer) from psoralen analogues 1-8. All the compounds were studied using the ab initio calculations in order to understand the relationship between the structures and their antitumor activity. 
The potential usefulness of psoralen-derived compounds as photosensitizers for PUVA therapy is now under investigation.

\section{Results and Discussion}

\subsection{Synthesis}

Compounds 1-4 (Scheme 1) were prepared from the corresponding hydroxybenzaldehydes via Knoevenagel type reaction [5]

Compound 5 was made by cyanation [7] of $\mathbf{1}$ in $81 \%$ yield. The replacement of the hydrogen atom by the cyano group was evident on the IR spectrum by a weak absorption at $2233 \mathrm{~cm}^{-1}$ and the disappearance of the most unshielded proton in the $1 \mathrm{H}$ NMR spectrum.

Compounds 6-8 needed the ortho-hydroxy ketone precursors, which were prepared by acid catalysed or photochemical Fries rearrangements [8]. From those precursors, the final compounds were obtained in $21-45 \%$ yields by a Knoevenagel type condensation, followed by ring closure where the carboxylic group present was activated with a phosphorus reagent [9] (Schemes 2, 3). The reaction products were characterized by spectroscopic methods and elemental analysis. For the compounds 6-8 the methyl group is evident in the ${ }^{1} \mathrm{H}$ NMR spectrum, at $2.56-3.00 \mathrm{ppm}$. For compound 8 a typical pattern for a $p$-substituted benzene ring was observed at $\delta 8.43$ and $7.80 \mathrm{ppm}(\mathrm{J}=8.7 \mathrm{~Hz})$ in the ${ }^{1} \mathrm{H}$ NMR spectrum.

\subsection{Effect on the growth of human tumor cell lines}

The effects of compounds on the growth of three human tumor cell lines, MCF-7 (breast cancer), NCI-H460 (non-small cell lung cancer) and SF-268 (CNS cancer) were 
evaluated. The growth inhibitory effects expressed as the concentration causing 50\% of cell growth inhibition $\left(\mathrm{GI}_{50}\right)$ are shown in Table 1 .

Only compounds 1, 4 and 8 exhibited, after a continuous exposure during a $48 \mathrm{~h}$ period, a dose-dependent growth inhibitory effect. Compound 1 was the most potent presenting $\mathrm{GI}_{50}$ values $\leq 20 \mu \mathrm{M}$ and inhibiting the growth of the three cell lines with the same potency. Compound 4 exhibited significant activity against MCF-7 and NCI-H460 but was less effective on the growth of SF-268. This different cell line response can reflect a possible tumor type-specific sensitivity of this compound. Compound $\mathbf{8}$ caused only a weak inhibition $(>50 \mu \mathrm{M})$ on the growth of the three cell lines.

\subsection{Molecular modeling}

All psoralen-derived compounds were studied using the ab initio calculations. This was performed by the definition of the optimised geometries and further calculation of the three-dimensional electrostatic potential isosurfaces (3D-EPI) and molecular electrostatic potential superimposed onto total electron density ((MEPSTED) (Figure 1). The three-dimensional MEP maps superimposed onto total electron density account for the interpretation of short-range interactions between molecules. At each point of the map, the electrostatic potential expresses the value of the electrostatic energy of interaction with a unitary positive charge. The three-dimensional MEP isosurfaces can account for the interpretation of long-range interactions with the receptor. This knowledge might allow the determination of an electrostatic pattern for the compounds that present the same activity. These isosurfaces have been determined at values of -10 and $10 \mathrm{kcal} / \mathrm{mol}$ (structural representations can be viewed in Schemes 1 $-3)$. 
For all compounds the MEP superimposed on the electron density shows that a negative potential is located over the oxygen atoms and a null to positive potential is located in the remaining parts of the structure. In the furan oxygen area the electrostatic profile is similar for all compounds. Through the three-dimensional MEP isosurfaces, it can be observed that all compounds present a negative potential located over the benzofuran ring, with the coumarin moiety showing positive values. Peripheral points of positive potential can also be seen around the aromatic area. The position of a bulk negative potential, due to the substituents present in the coumarin moiety of the molecule, differentiates the psoralens, with compounds $\mathbf{1}$ and $\mathbf{4}$ presenting analogue electrostatic potential isosurfaces. Compound $\mathbf{4}$, which is conformationally alike to compound $\mathbf{1}$, presented the second best set of results except for tumor cell line SF-268. Compound 4 possesses a similar active region to compound $\mathbf{1}$, but shows an increase in the electronic density due to the vicinity of an oxygen atom from the coumarin moiety, which could explain the difference in the activity results. Although the similar global conformation of molecules 1 and $\mathbf{4}$, the position of the ester groups is inverted, changing the pattern of the electronic densities in both molecules. The lack of activity of compounds $\mathbf{5}$ and $\mathbf{6}$, which present a similar distribution of electrostatic potential, seems to be related with the presence of the cyano and methyl groups. For these compounds, the interactions with the bioreceptor are impaired by steric (conformational distortion and increase of the molecular volume in one of the points of interaction) and electronic density factors, caused by the cyano and methyl substituents mainly on the ester group. Besides conformational distortion and increase of the molecular volume in both compounds, the presence of the cyano group in compound $\mathbf{5}$ increases substantially the electronic density near the carbonyl from the ester group, whereas the presence of a methyl group in compound $\mathbf{6}$ reduces it substantially. 
The other compounds do not have the minimal structural conformation to interact with the bioreceptor. Compounds 2, 3 and $\mathbf{7}$ are inactive and present an electrostatic contour that differs from the active analogues, due to a different orientation of the entire coumarin moiety. Although compound $\mathbf{8}$ presents similar structural features to compounds 3 and 7, it exhibits some degree of activity, which can be associated with the nitro group originating a point of very intense negative potential.

Based on the analysis of the 3D-EPI/MEP-STED for compounds $\mathbf{1 , 4 , 5}$ and $\mathbf{6}$, we propose a model for the interactions between the bioactive and the bioreceptor, shown in Figure.2, involving at least four specific interactions, being three polar and one apolar, involving the ethyl group.

\section{Conclusions}

The successful synthesis of four new benzofurocoumarin is described. The use of the phenyl dichlorophosphate as activating reagent for the final cyclisation giving $\mathbf{6 - 8}$ may have been determinant since the ketonic starting materials were not, in principle, very reactive.

Eight compounds were tested and two of them showed significant activity on the in vitro tests on inhibition of the growth of three human tumor cell lines, suggesting that compounds with similar distribution of electronic density and molecular conformation will be also active for this purpose.

The understanding of the correlation of the activity of the compounds described with their molecular properties can help defining future target compounds with increased biological activity. 


\section{Experimental}

\subsection{Synthesis}

Light petroleum refers to solvent boiling in the range $40-60^{\circ} \mathrm{C}$. Column chromatography (CC) was performed on Merck silica gel 60 (70-230 mesh). Melting points were determined on a Gallenkamp apparatus and are uncorrected. Ultraviolet spectra were recorded in ethanol on a SHIMADZU UV-2501 PC and data are presented in $\lambda_{\max }(\mathrm{nm}),\left(\log \varepsilon\left[\mathrm{mol}^{-1} \mathrm{dm}^{3} \mathrm{~cm}^{-1}\right]\right)$. Infrared spectra were recorded on a Diffus-IR Bomem MB-Series FTIR spectrometer in $\mathrm{cm}^{-1}$. NMR spectra were obtained on a Varian Unity Plus at $300 \mathrm{MHz}\left({ }^{1} \mathrm{H}\right)$ and $75.4\left({ }^{13} \mathrm{C}\right)$ and the assignments were based on irradiation and 2D-NMR techniques (HMQC and HMBC), respectively. The solvent was $\mathrm{CDCl}_{3}$ (if not stated otherwise) and $\delta$ is in ppm, relative to internal $\mathrm{SiMe}_{4}$. Elemental analyses were carried out with a LECO CHNS-932. EIMS and HRMS spectra were carried out with an AutoSpecE spectrometer, in $m / z$ (rel. \%).

Ethyl 1-cyano-3-oxo-3H-benzofuro[3,2-f]-1-benzopyran-2-carboxylate (5)

Compound $1(0.040 \mathrm{~g}, 0.13 \mathrm{mmol})$ was dissolved in DMF $\left(2,0 \mathrm{~cm}^{3}\right)$ and sodium cyanide $(0.013 \mathrm{~g}, 0.26 \mathrm{mmol})$ was added and the mixture heated at $45^{\circ} \mathrm{C}$, with stirring for $1 \mathrm{~h}$. After cooling to $0{ }^{\circ} \mathrm{C}$, bromine $(0.027 \mathrm{~g}, 0.17 \mathrm{mmol})$, dissolved in DMF $(0.5$ $\mathrm{cm}^{3}$ ), was added dropwise for $2 \mathrm{~h}$. The mixture was kept at room temperature, stirring, for $24 \mathrm{~h}$. Water was added to the mixture $\left(10 \mathrm{~cm}^{3}\right)$, compound 5 precipitated and was filtered $(0.035 \mathrm{mg}, 81 \%)$. Recrystallization from hot ethanol gave intense yellow crystals. M.p.: 198.5-200.0 ㄷ․ UV: 368 (4.14); 271 (4.20). IR (KBr): 2233 (CN), 1736 $(\mathrm{s}, \mathrm{C}=\mathrm{O}), 1727(\mathrm{~s}, \mathrm{C}=\mathrm{O}), 1584,1555,1468,1418,1368,1347,1289,1245,1228,1106$, 1066, 1048, 855, 821, 768, 757, 700, 665. ${ }^{1} \mathrm{H} \mathrm{NMR}, \delta: 1.51$ (t, 3H, J=7.1 Hz, $\mathrm{CH}_{2} \mathrm{CH}_{3}$ ), 
4.59 (q, 2H, $\left.J=7.1 \mathrm{~Hz}, \mathrm{CH}_{2} \mathrm{CH}_{3}\right), 7.49$ (dt, 1H, J=7.8, $\left.1.0 \mathrm{~Hz}, 10-\mathrm{CH}\right), 7.54$ (d, 1H, $J=9.0 \mathrm{~Hz}, 6-\mathrm{CH}$ or $5-\mathrm{CH}), 7.63(\mathrm{dt}, 1 \mathrm{H}, J=7.8,1.0 \mathrm{~Hz}, 9-\mathrm{CH}), 7.70(b r \mathrm{~d}, 1 \mathrm{H}, J=7.8 \mathrm{~Hz}$, 8-CH), $7.96(\mathrm{~d}, 1 \mathrm{H}, J=9.0 \mathrm{~Hz}, 5-\mathrm{CH}$ or $6-\mathrm{CH}), 8.97(\mathrm{br} \mathrm{d}, 1 \mathrm{H}, J=7.8 \mathrm{~Hz}, 11-\mathrm{CH}) .{ }^{13} \mathrm{C}$ NMR, \&: $13.90\left(\mathrm{CH}_{2} \mathrm{CH}_{3}\right), 63.75\left(\mathrm{CH}_{2} \mathrm{CH}_{3}\right), 110.37,112.19(\mathrm{CH}), 115.07,116.57(\mathrm{CH})$, $118.69(\mathrm{CH}), 120.23,121.79,122.40,123.53(\mathrm{CH}), 126.23(\mathrm{CH}), 129.15(\mathrm{CH}), 130.36$, 151.27, 153.13, 154.87, 157.29, $161.61\left(\mathrm{CO}_{2}\right.$ Et). EI-MS, $m / z: 334\left(21,[M+1]^{+}\right), 333$ $\left(100, M^{+}\right), 305(32), 304$ (67), 288 (44), 277 (40), 261 (17), 233 (28), 204 (36), 175 (9). HRMS: $331.0631\left(M^{+}, \mathrm{C}_{19} \mathrm{H}_{11} \mathrm{NO}_{5}^{+}\right.$; calc. 333.0637).

Ethyl 1-methyl-3-oxo-3H-benzofuro[3,2-f]-1-benzopyran-2-carboxylate (6) A mixture of 2-hydroxydibenzofuran-1-yl methyl ketone (0.094 g, $0.42 \mathrm{mmol}), 1,8$ diazabicyclo[5.4.0]undec-7-ene (DBU) $(0.24 \mathrm{ml}, 1.6 \mathrm{mmol})$ and mono-ethylmalonate $(0.070 \mathrm{~g}, 0.53 \mathrm{mmol})$ dissolved in 1,2-dichlorobenzene $\left(1.2 \mathrm{~cm}^{3}\right)$ was kept at $0{ }^{\circ} \mathrm{C}$ and phenyl dichlorophosphate $\left(0.11 \mathrm{~cm}^{3}, 0.74 \mathrm{mmol}\right)$ was added dropwise with stirring. The mixture was kept in these conditions for $30 \mathrm{~min}$ and then was heated at $145^{\circ} \mathrm{C}$ for $2 \mathrm{~h} 30$ min. The mixture was poured onto crushed ice, extracted with dichloromethane $(3 \times 25$ $\left.\mathrm{cm}^{3}\right)$, dried $\left(\mathrm{MgSO}_{4}\right)$ and evaporated. The residue was separated by column cromatography (silica gel, ethyl acetate / light petroleum). The first compound eluted was the starting ketone $(0.029 \mathrm{~g}, 31 \%)$. The second compound eluted was coumarin 6 $(0.030 \mathrm{~g}, 22 \%)$. Recrystallization from $\mathrm{CHCl}_{3}$ and hexane gave compound $\mathbf{6}$ as a light yellow solid (0.030, 22 \%). M.p. $151.5-153.0^{\circ} \mathrm{C} . \mathrm{UV}: 332$ (4.34). IR (KBr): 1731 $(\mathrm{C}=\mathrm{O}), 1707(\mathrm{C}=\mathrm{O}), 1586,1466,1438,1368,1352,1300,1285,1248,1233,1103$, 1058, 820, 747. ${ }^{1} \mathrm{H} \mathrm{NMR}, \delta: 1.46\left(\mathrm{t}, 3 \mathrm{H}, J=7.1 \mathrm{~Hz}, \mathrm{CH}_{2} \mathrm{CH}_{3}\right), 3.00\left(\mathrm{~s}, 3 \mathrm{H}, \mathrm{CH}_{3}\right), 4.50$ (q, 2H, $\left.J=7.1 \mathrm{~Hz}, \mathrm{CH}_{2} \mathrm{CH}_{3}\right), 7.40(\mathrm{dt}, 1 \mathrm{H}, J=7.8,1.0 \mathrm{~Hz}, 10-\mathrm{CH}), 7.52(\mathrm{~d}, 1 \mathrm{H}, J=9.0 \mathrm{~Hz}$, 6-CH or 5-CH), 7.57 (dt, 1H, J=7.8, 1.0 Hz, 9-CH), $7.92(b r \mathrm{~d}, 1 \mathrm{H}, J=7.8 \mathrm{~Hz}, 8-\mathrm{CH})$, 
$7.84(\mathrm{~d}, 1 \mathrm{H}, J=9.0 \mathrm{~Hz}, 5-\mathrm{CH}$ or $6-\mathrm{CH}), 8.26(b r \mathrm{~d}, 1 \mathrm{H}, J=7.8 \mathrm{~Hz}, 11-\mathrm{CH}) .{ }^{13} \mathrm{C} \mathrm{NMR}, \delta$ : $14.14\left(\mathrm{CH}_{2} \mathrm{CH}_{3}\right), 20.99\left(\mathrm{Ar}-\mathrm{CH}_{3}\right), 62.22\left(\mathrm{CH}_{2} \mathrm{CH}_{3}\right), 112.47(\mathrm{CH}), 115.55,116.70(\mathrm{CH})$, $117.12(\mathrm{CH}), 120.36,121.80,122.74,122.98(\mathrm{CH}), 124.98(\mathrm{CH}), 128.10(\mathrm{CH}), 150.28$, 150.61, 153.25, 157.19, 165.04, 171.10. EIMS, $m / z: 322\left(16, M^{+}\right), 306(8), 277(23)$, 276 (100), 250 (16), 208 (17), 165 (14). HRMS: $322.0825\left(M^{+}, \mathrm{C}_{19} \mathrm{H}_{14} \mathrm{O}_{5}^{+}\right.$; calc. 322.0841). Anal. calcd for $\mathrm{C}_{19} \mathrm{H}_{14} \mathrm{O}_{5}$ : C, 70.80; H, 4.38 \%. Found: C, 70.66, H, $4.51 \%$.

Ethyl 1-methyl-2-oxo-2H-benzofuro[2,3-g]-1-benzopyran-3-carboxylate (7) A mixture of 2-hydroxydibenzofuran-3-yl methyl ketone (0.120 g, $0.531 \mathrm{mmol})$, triethylamine $(0.161 \mathrm{~g}, 1.59 \mathrm{mmol})$ and mono-ethylmalonate $(0.080 \mathrm{~g}, 0.61 \mathrm{mmol})$ dissolved in 1,2-dichloroethane $\left(8 \mathrm{~cm}^{3}\right)$ was kept at $0{ }^{\circ} \mathrm{C}$ and phenyl dichlorophosphate $(0.130 \mathrm{~g}, 0.616 \mathrm{mmol})$ was added drop wise with stirring. The mixture was kept in these conditions for $30 \mathrm{~min}$ and then it was heated at reflux for $4 \mathrm{~h}$. After cooling, water (20 $\left.\mathrm{cm}^{3}\right)$ and diethyl ether $\left(20 \mathrm{~cm}^{3}\right)$ were added. The organic phase was separated, dried $\left(\mathrm{MgSO}_{4}\right)$, the solvent was evaporated and the residue was purified by column cromatography (silica gel, ethyl acetate / light petroleum). The first compound eluted was the starting ketone $(0.064 \mathrm{~g}, 53 \%)$. The second compound eluted was coumarine 7 $(0.077 \mathrm{~g}, 45 \%)$. Recrystallization from hot ethanol gave compound 7 as yellow crystals. M.p. $234.5-236.0{ }^{\circ} \mathrm{C} . \mathrm{UV}: 331$ (4.50). IR (KBr): 2988, $1734(\mathrm{C}=\mathrm{O}), 1698(\mathrm{C}=\mathrm{O}), 1642$, $1625,1573,1458,1430,1401,1375,1338,1300,1278,1233,1206,1149,1081,1059$,

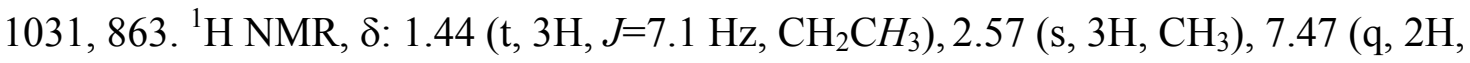
$\left.J=7.1 \mathrm{~Hz}, \mathrm{CH}_{2} \mathrm{CH}_{3}\right), 7.45-7.39(\mathrm{~m}, 1 \mathrm{H}, 9-\mathrm{CH}), 7.63-7.55(\mathrm{~m}, 2 \mathrm{H}, 7-\mathrm{CH}$ and 8-CH), $7.83(\mathrm{~s}, 1 \mathrm{H}, 5-\mathrm{CH}$ or $11-\mathrm{CH}), 7.87(\mathrm{~s}, 1 \mathrm{H}, 11-\mathrm{CH}$ or $5-\mathrm{CH}), 8.02(\mathrm{br} \mathrm{d}, 1 \mathrm{H}, J=7.8 \mathrm{~Hz}$, 10-CH). ${ }^{13} \mathrm{C} \mathrm{NMR,} \mathrm{\delta :} 14.18\left(\mathrm{CH}_{2} \mathrm{CH}_{3}\right), 16.48\left(\mathrm{CH}_{3}\right), 62.22\left(\mathrm{CH}_{2} \mathrm{CH}_{3}\right), 107.04(5-\mathrm{CH}$ or 11-CH), 108.30 (5-CH or 11-CH), 112.053 (7-CH or 8-CH), 118.18, 121.07, 121.85 
(10-CH), 123.00, 123.42 (9-CH), 128.73, 129.54 (7-CH or 8-CH), 149.17, 149.92, 152.57, 157.96, 164.96, 171.15. EIMS, $m / z: 323\left(2,[M+1]^{+}\right), 322\left(61, M^{+}\right), 306(6)$, 277 (51), 276 (100), 250 (12), 208 (17), 165 (10). HRMS: $322.0836\left(M^{+}, \mathrm{C}_{19} \mathrm{H}_{14} \mathrm{O}_{5}{ }^{+}\right.$; calc. 322.0841). Anal. calcd for $\mathrm{C}_{19} \mathrm{H}_{14} \mathrm{O}_{5}$ : C, 70.80; H, $4.38 \%$. Found: C, 70.57; H, $4.58 \%$.

4-methyl-3-(4'-nitrophenyl)-benzofuro[2,3-g]benzopyranone (8)

To a mixture of 2-hydroxydibenzofuran-3-yl methyl ketone $(0.119 \mathrm{~g}, 0.526 \mathrm{mmol})$, triethylamine $(0.177 \mathrm{~g}, 1.75 \mathrm{mmol})$ and 4-nitrophenylacetic acid $(0.102 \mathrm{~g}, 0.564 \mathrm{mmol})$ dissolved in 1,2-dichloroethane $\left(6 \mathrm{~cm}^{3}\right)$, at $0{ }^{\circ} \mathrm{C}$, phenyl dichlorophosphate $(0.130 \mathrm{~g}$, $0.616 \mathrm{mmol}$ ) was added drop wise with stirring. The mixture was kept in these conditions for $30 \mathrm{~min}$ and then it was heated at reflux for $3 \mathrm{~h} 30 \mathrm{~min}$. Water was added $\left(15 \mathrm{~cm}^{3}\right)$ and the mixture was extracted with ethyl acetate $\left(3 \mathrm{x} 15 \mathrm{~cm}^{3}\right)$, dried $\left(\mathrm{MgSO}_{4}\right)$ and the solvent evaporated. From the residue, compound $\mathbf{8}$ was precipitated with propanone / light petroleum $(0.040 \mathrm{~g}, 21 \%)$. Recrystallisation from ethyl acetate / trichloromethane gave yellow crystals. M.p. $>300^{\circ} \mathrm{C}$ (dec.). UV: 336 (4.56). IR (KBr): $1698(\mathrm{C}=\mathrm{O}), 1643,1597,1569,1517,1345,1331,1143,983,856,768 .{ }^{1} \mathrm{H}$ NMR (acetone- $\left.\mathrm{d}_{6}\right), \delta: 2.56\left(\mathrm{~s}, 3 \mathrm{H}, \mathrm{CH}_{3}\right), 7.54(\mathrm{dt}, 1 \mathrm{H}, J=7.8,1.0 \mathrm{~Hz}, 9-\mathrm{CH}), 7.71(\mathrm{dt}, 1 \mathrm{H}$, $J=7.8,1.0 \mathrm{~Hz}, 8-\mathrm{CH}), 7.77(b r \mathrm{~d}, 1 \mathrm{H}, J=7.8 \mathrm{~Hz}, 7-\mathrm{CH}), 7.80$ (d, 2H, $J=8.7 \mathrm{~Hz} 2^{\prime}-\mathrm{CH}$ and $\left.6^{\prime}-\mathrm{CH}\right), 8.21(\mathrm{~s}, 2 \mathrm{H}, 5-\mathrm{CH}$ and 11-CH), $8.32(b r \mathrm{~d}, 1 \mathrm{H}, J=7.8 \mathrm{~Hz}, 10-\mathrm{CH}), 8.43(\mathrm{~d}$, $2 \mathrm{H}, J=8.7 \mathrm{~Hz}, 3^{\prime}-\mathrm{CH}$ and $\left.5^{\prime}-\mathrm{CH}\right) .{ }^{13} \mathrm{C} \mathrm{NMR}, \delta: 17.14\left(\mathrm{CH}_{3}\right), 106.97(\mathrm{CH}), 108.19(\mathrm{CH})$, $112.06(\mathrm{CH}), 116.32,119.13,121.82(\mathrm{CH}), 123.12,123.41(\mathrm{CH}), 123.67\left(2 \mathrm{C} ; 2^{\prime}-\mathrm{CH}\right.$ and 6'-CH), 125.05, 128.20, $129.41(\mathrm{CH}), 131.47$ (2C; 3'-CH and 5'-CH), 141.41, $147.66,148.99,152.65,157.95$ (it is not possible to assign the exact location of the 
signal of $C O)$. EIMS, $m / z$ : $372\left(25,[M+1]^{+}\right), 371\left(100,[M]^{+}\right), 343(21), 297(8), 268$

(9), 239 (7), 221(4). HRMS: 371.0797 ([M] ${ }^{+}, \mathrm{C}_{22} \mathrm{H}_{13} \mathrm{NO}_{5}^{+}$; calc. 371.0794).

\subsection{Tumor cell growth assay}

Stock solutions of compounds were prepared in DMSO (Sigma Chemical Co) and stored at $-20^{\circ} \mathrm{C}$. The frozen samples were freshly diluted with cell culture medium just prior the assay. Final concentrations of DMSO did not interfere with the cell growth.

The effects of compounds on the growth of human tumor cell lines were evaluated according to the procedure adopted by the National Cancer Institute (NCI, USA) for the in vitro anticancer drug screening that use the protein-binding dye sulforhodamine B (Sigma Chemical Co) to assess growth inhibition. The methodology used was the same as originally published by the NCI team [10]. Three human tumor cell lines were used, MCF-7 (breast adenocarcinoma), NCI-H460 (non-small cell lung cancer) and SF-268 (CNS cancer). Cells were routinely maintained as adherent cell cultures in RPMI-1640 medium (Gibco BRL) containing $5 \%$ heat-inactivated FBS (Gibco BRL), $2 \mathrm{mM}$ glutamine (Sigma Chemical Co) and $50 \mu \mathrm{g} / \mathrm{ml}$ gentamicin (Sigma Chemical Co) at $37{ }^{\circ} \mathrm{C}$ in an humidified air incubator containing $5 \% \mathrm{CO}_{2}$. The optimal plating density of each cell line that ensure exponential growth throughout all the experimental period, was the same as originally published ${ }^{2}$ and was respectively $1.5 \times 10^{5}$ cells $/ \mathrm{ml}$ to MCF-7 and SF-268 and $7.5 \times 10^{4}$ cells $/ \mathrm{ml}$ to NCI-H460. Cells were exposed for $48 \mathrm{~h}$ to five concentrations of compounds starting from a maximum of $150 \mu \mathrm{M}$. Compound 2 was tested at a maximum of $100 \mu \mathrm{M}$. Doxorubicin (Sigma Chemical Co) used as a positive control, was tested in the same manner. For each test 
compound and for each cell line a dose-response curve was generated and the growth inhibition of $50 \%\left(\mathrm{GI}_{50}\right)$ was calculated as described [11].

\subsection{Computational procedure}

All calculations were performed with Gamess 6.3 [12]. Geometry optimizations and energy calculations were performed on each compound at the ab initio quantum mechanical level by using Density Functional Theory (DFT) with the Becke3-LeeYang-Parr (B3LYP) functional, and the 6-31G(d) basis set. All calculations have been carried out in vacuo.

Visualization of all the results was performed with Molekel 4.3 [13].

Molecular Electrostatic Potential (MEP) surfaces were drawn using the CALCULATE utility present in Molekel 4.3, applied to the optimized geometries of all molecules. The MEP isoenergy contours were generated in the range of -60 to 60 $\mathrm{kcal} / \mathrm{mol}$, superimposed onto a surface of constant electron density $\left(0.0002 \mathrm{e} / \mathrm{au}^{3}\right)$, to provide a measure of the electrostatic potential at roughly the van der Waals surface of the molecule. This colour-coded surface provides a measure of the overall size of the molecule as well as the location of negative or positive electrostatic potentials. The regions of positive electrostatic potential indicate excess positive charge, leading to repulsion of the positively charged test probe, while regions of negative potential indicate areas of excess negative charge, leading to attraction of the positively charged test probe. Three-dimensional surfaces of molecular electrostatic potential at the constant values of -10 and $10 \mathrm{kcal} / \mathrm{mol}$ were generated to determine the profile of the electrostatic potential of a molecule when approaching the receptor. 


\section{Acknowledgements}

For financial support from Fundação para a Ciência e Tecnologia - Portugal (I\&D n ${ }^{\circ} 226 / 9$ and to CQ-UM), POCTI and FEDER; PhD grants from FCT: Ana M. A. G. Oliveira (PRAXIS XXI/BD/19707/99), Madalena Pedro (SFRH/BD/1456/2000) and César Portela (SFRH/BD/3036/2000). For financial support and research grants to FAPEMIG (Fundação de Amparo à Pesquisa do Estado de Minas Gerais) and CNPq (Conselho Nacional do Desenvolvimento Científico e Tecnológico - Brasil). The authors thank National Cancer Institute, Bethesda, MD (USA) for kindly providing the tumor cell lines and Elisa Pinto for obtaining ${ }^{1} \mathrm{H}$ NMR and ${ }^{13} \mathrm{C}$ NMR spectra and elemental analyses. 


\section{References}

[1] a) Chilin, A.; Marzano, C.; Guiotto, A.; Manzini, P.; Baccichetti, F.; Carlassare, F.; Bordin, F. J. Med. Chem. 42 (15) (1999) 2936; b) Mobilio, S.; Tondelli, L.;

Capobianco, M.; Gia, O. Photochem. Photobio. 61 (1995) 113; c) Palumbo, M.;

Rodighiero, P.; Gia, O.; Guiotto, A.; Marciani, M. S. Photochem. Photobio 44 (1986) 1.

[2] Gia, O.; Mobilio, S.; Palumbo, M.; Pathak, M. A. Photochem. Photobiol. 57 (1993) 497.

[3]. a) Bordin, F. Int. J. Photoenergy , 1 (1999) 1 b) Dall'Acqua, F.; Vedaldi, D.;

Caffieri, S. In “The Fundamental Bases of Phototherapy”, Hönigsmann, H.; Jori, G.;

Young, A. R. (Eds.), OEMF, Milano 1996, p. 1.

[4] Dall'Acqua, F.; Vedaldi, D.; Guiotto, A.; Rodighiero, P.; Carassare, F.; Baccichetti, F.; Bordin, F. J. Med. Chem. 24 (1981) 806.

[5] Leite, V. C.; Santos, R. F.; Chen, L. C.; Guillo, L. A. J. Photochem. Photobiology B: Biol. 76 (2004) 49.

[5] Oliveira, A. M. A. G.; Raposo, M. M. M.; Oliveira-Campos, A. M. F.; Griffiths, J. and Machado, A. E. H. Helv. Chim. Acta 86 (2003) 2900.

[6]. Machado, A. E. H.; Miranda, J. A., Oliveira-Campos, A. M. F.; Severino, D.;

Nicodem, D. E. J. Photochem. Photobiol. A: Chemistry 146 (2001) 75.

[7]. Luo, X.; Naiyun, X.; Cheng, L.; Huang, D. Dyes and Pigments , 51 (2001) 153.

[8]. Oliveira, A. M. A. G.; Raposo, M. M. M.; Oliveira-Campos, A. M. F.; Griffiths, J.; Machado, A. E. H. Tetrahedron, 60 (2004) 6145.

[9]. Gallastegui, J.; Lago, J. M.; Palomo, C. J. Chem. Research (S) 1984, 170.

[10]. Skehan, P.; Storeng, R.; Scudiero, D.; Monks, A.; McMahon, J.; Vistica, D.;

Warren, J.T.; Bokesch, H.; Kenney, S.; Boyd, M. R. J. Natl. Cancer Inst. 82 (1990) 1107. 
[11]. Monks, A.; Scudiero, D.; Skehan, P.; Shoemaker, R.; Paull, K.; Vistica, D.; Hose,

C.; Langley, J.; Cronise, P.; Vaigro-Wolff, A.; Gray-Goodrich, M.; Campbell, H.;

Mayo, J.; Boyd, M. J. Natl. Cancer Inst. 83 (1991) 757.

[12]. Schmidt, M. W.; Baldridge, K. K.; Boatz, J. A.; Elbert, S. T.; Gordon, M. S.;

Jensen, J. H.; Koseki, S.; Matsunaga, N.; Nguyen, K. A.; Su, S. J., Windus, T. L.;

Dupuis, M.; Montgomery J. A. J. Comput. Chem. 14 (1993) 1347.

[13]. Portmann, S.; Lüthi, H. P. CHIMIA 54 (2000) 766. 


\section{Figure captions}

Figure 1: Three-dimensional electrostatic potential isosurfaces at $-10 \mathrm{kcal} / \mathrm{mol}$ (blue) and $10 \mathrm{kcal} / \mathrm{mol}$ (light grey) for compounds 1-8 and MEPs superimposed onto total electron density at a value of $0.0002 \mathrm{e} / \mathrm{au}^{3}$ for compounds $\mathbf{1 - 8}$.

Figure 2: Schematic representation of the interaction between compound $\mathbf{1}$ and a bioreceptor of tumor cell, indicating four levels of interaction: 1, 3 and 4, Polar; 2 , Apolar.

\section{Scheme captions}

Scheme 1: Structural representation of compounds 1-5

Scheme 2: Reaction conditions for the obtention of compound $\mathbf{6 .}$

Scheme 3: Reaction conditions for the obtention of compounds 7 and $\mathbf{8 .}$ 
Table 1. Effect of compounds on the growth of human tumor cell lines

\begin{tabular}{clll} 
& \multicolumn{1}{c}{$\mathbf{G I}_{\mathbf{5 0}}(\boldsymbol{\mu M})$} & & \\
$\mathbf{C}$ & $\mathbf{M C F}-\mathbf{7}$ & NCI-H460 & SF-268 \\
\cline { 2 - 3 } $\mathbf{1}$ & $>13.9 \pm 1.2$ & $20.4 \pm 1.1$ & $17.6 \pm 1.4$ \\
$\mathbf{2}$ & $>100$ & $>100$ \\
$\mathbf{3}$ & $>150$ & $>150$ & $120.3 \pm 8.4$ \\
$\mathbf{4}$ & $19.4 \pm 1.9$ & $31.2 \pm 1.8$ & $115.7 \pm 10.2$ \\
$\mathbf{5}$ & $>150$ & $>150$ & $>150$ \\
$\mathbf{6}$ & $>150$ & $>150$ & $>150$ \\
$\mathbf{7}$ & $>150$ & $>150$ & $>150$ \\
$\mathbf{8}$ & $58.4 \pm 8.8$ & $82.7 \pm 4.5$ & $72.7 \pm 1.6$
\end{tabular}

Doxorubicin, $\mathrm{GI}_{50}: \mathrm{MCF}-7=42.8 \pm 8.2 \mathrm{nM} ; \mathrm{NCI}-\mathrm{H} 460=94.0 \pm 8.7 \mathrm{nM} ; \mathrm{SF}-268=93.0 \pm 7.0 \mathrm{nM}$; results are means \pm SEM of 6-9 independent experiments. 


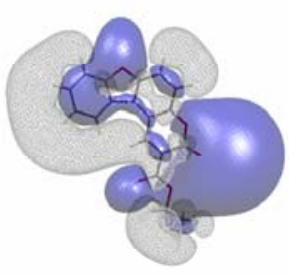

1
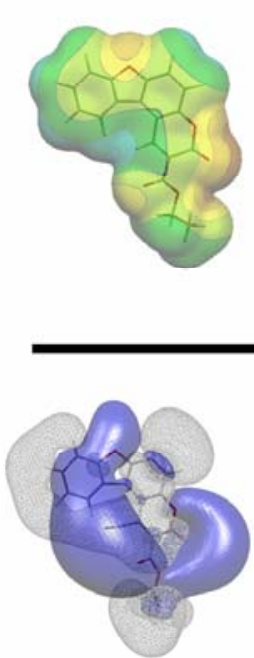

5

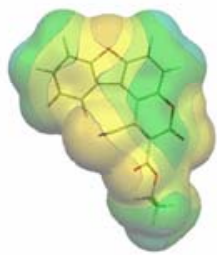

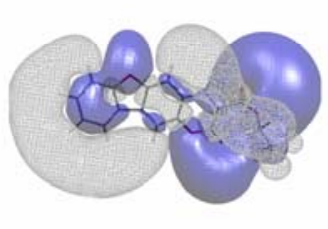

2

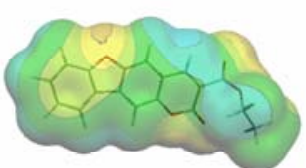

$\mathrm{Keal} / \mathrm{mol}$

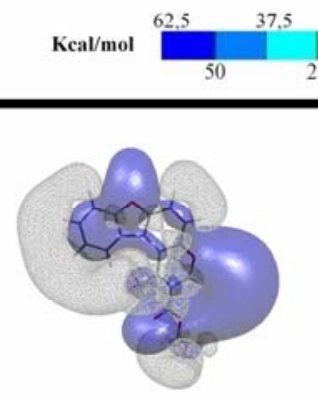

6
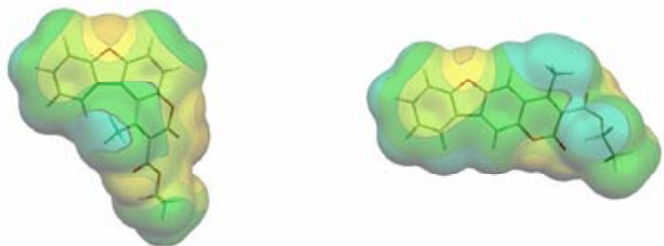

Keal/mol

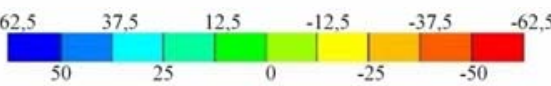
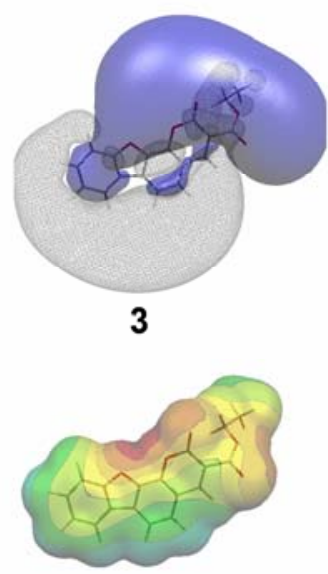

4
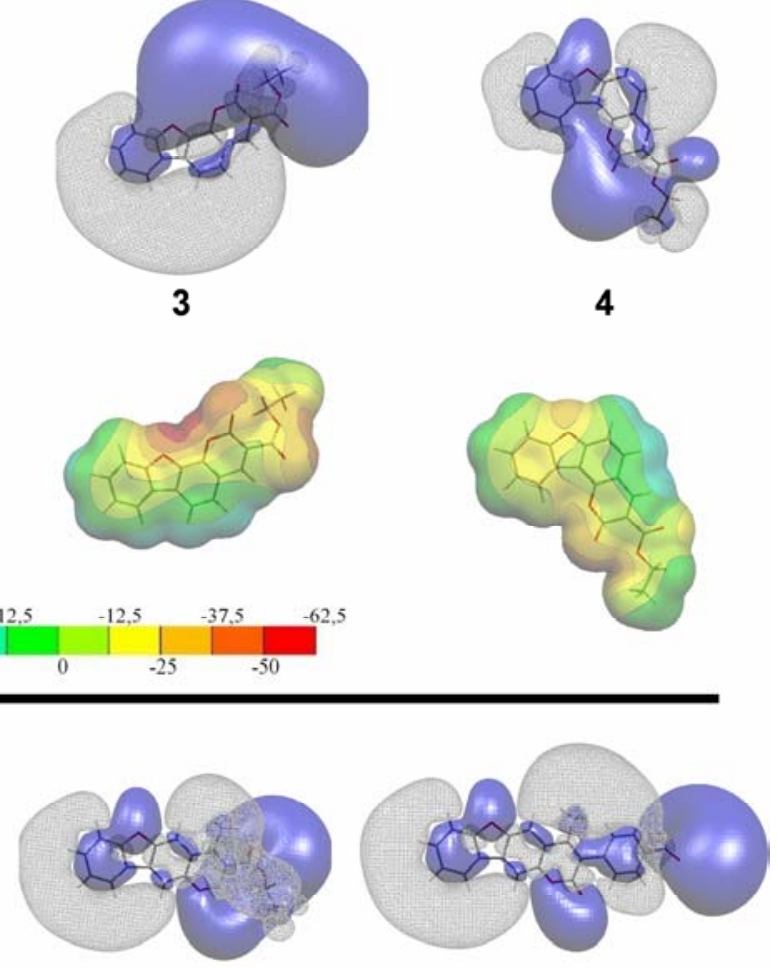

8

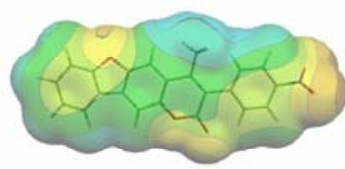

Figure 1 


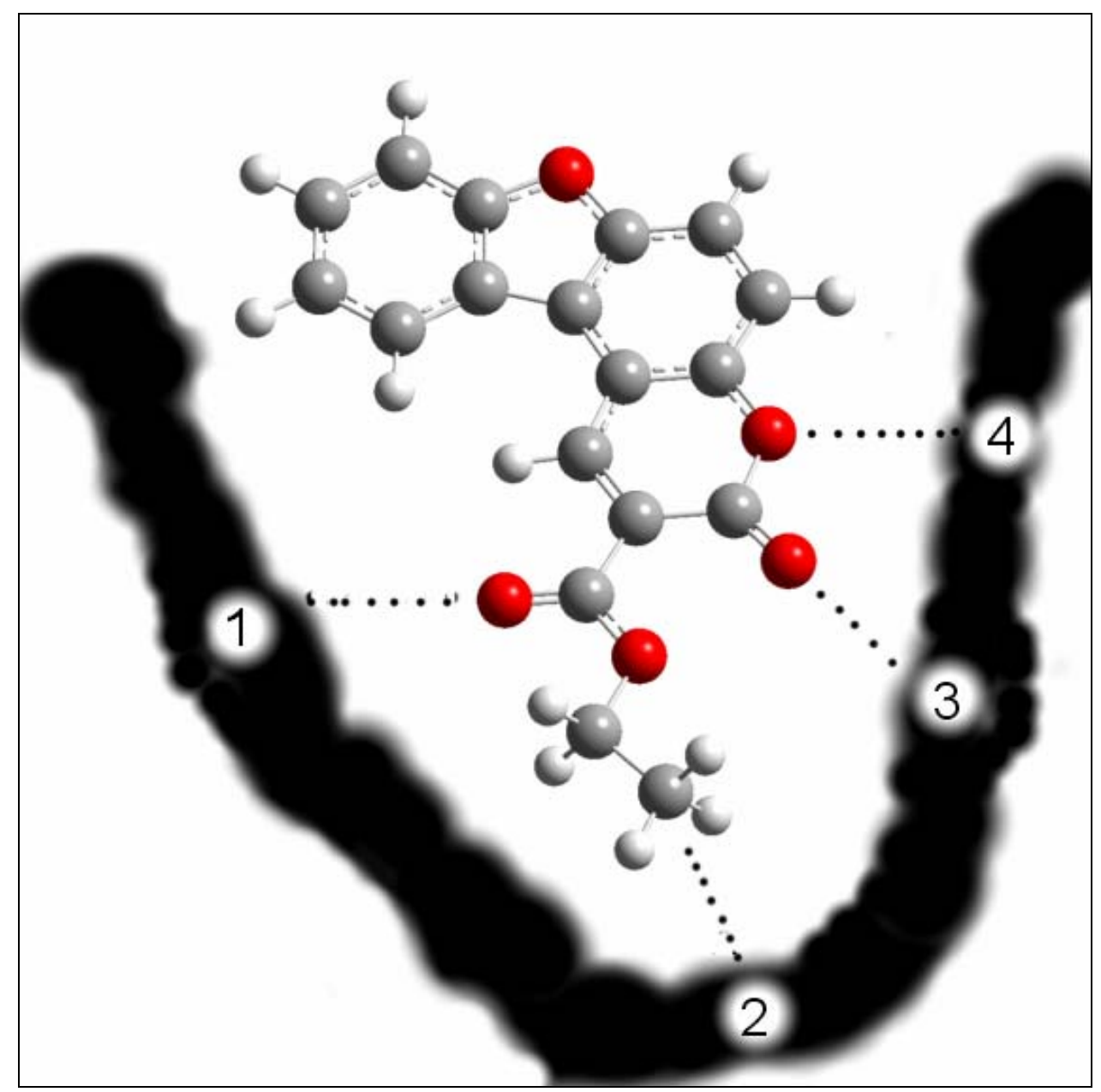

Figure 2 


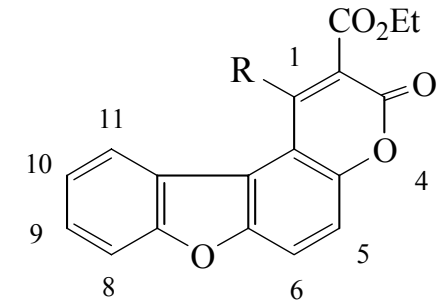

1: $\mathrm{R}=\mathrm{H}$

5: $\mathrm{R}=\mathrm{CN}$

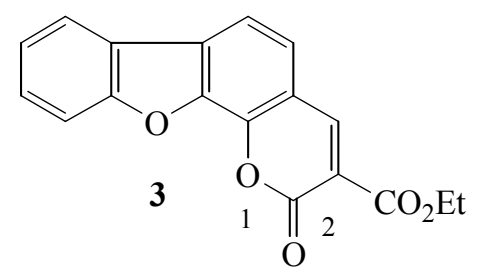

Scheme 1
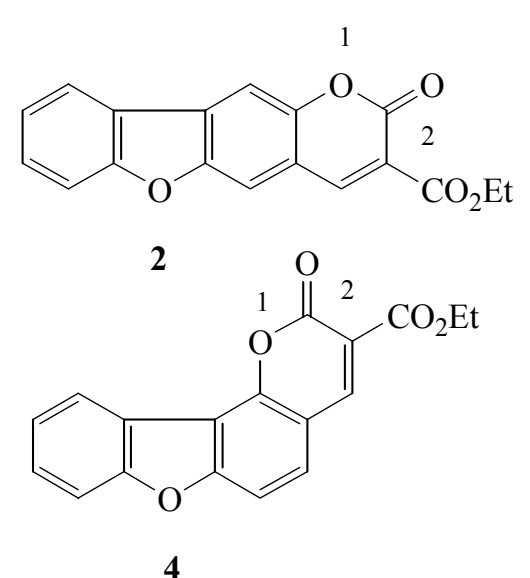


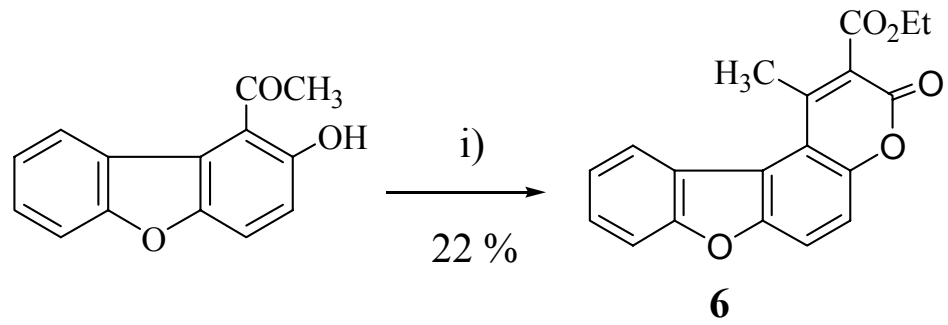

Reagents and conditions: i) $\mathrm{C}_{6} \mathrm{H}_{4} \mathrm{Cl}_{2}, \mathrm{DBU}, \mathrm{C}_{6} \mathrm{H}_{5} \mathrm{OP}(\mathrm{O}) \mathrm{Cl}_{2}, \mathrm{HO}_{2} \mathrm{CCH}_{2} \mathrm{CO}_{2} \mathrm{C}_{2} \mathrm{H}_{5} ; 145$ ${ }^{\circ} \mathrm{C}$.

Scheme 2. 
<smiles>CC(=O)c1cc2oc3ccccc3c2cc1O</smiles><smiles></smiles>

Reagents and conditions: $\mathrm{CH}_{2} \mathrm{ClCH}_{2} \mathrm{Cl}, \mathrm{NEt}_{3}, \mathrm{C}_{6} \mathrm{H}_{5} \mathrm{OP}(\mathrm{O}) \mathrm{Cl}_{2}$;

i) $\mathrm{HO}_{2} \mathrm{CCH}_{2} \mathrm{CO}_{2} \mathrm{C}_{2} \mathrm{H}_{5}$; reflux. ii) $\mathrm{HO}_{2} \mathrm{CH}_{2} \mathrm{C}_{6} \mathrm{H}_{4} \mathrm{NO}_{2}$; reflux.

Scheme 3 